\title{
Digital Profile of Klebsiella Pneumoniae Strains Producing Extended Spectrum $\beta$-Lactamase Isolated in Hospitals in the Littoral Region of Cameroon
}

\author{
Jean Teghonong ${ }^{1,2, *}$, Cecile Okalla Ebongue ${ }^{3}$, Callixte Yadufashije ${ }^{4}$, Dieudonne Adiogo ${ }^{3}$ \\ ${ }^{1}$ Department of Biological Sciences, Distant Production House University, Uvira, Democratic Republic of Congo \\ ${ }^{2}$ Diagmed Laboratory, Douala, Cameroon \\ ${ }^{3}$ Department of Biological Sciences, Douala University, Douala, Cameroon \\ ${ }^{4}$ INES-Ruhengeri - Institute of Applied Sciences, Musanze, Rwanda
}

Email address:

jeanteghonong@yahoo.fr(J. Teghonong),cecileokalla@yahoo.fr(C. O. Ebongue),cyadufashije@gmail.com(C. Yadufashije), d_adiogo@yahoo.fr(D. Adiogo)

${ }^{*}$ Corresponding author

\section{To cite this article:}

Jean Teghonong, Cécile Okalla Ebongue, Callixte Yadufashije, Dieudonné Adiogo. Digital Profile of Klebsiella Pneumoniae Strains Producing Extended Spectrum $\beta$-Lactamase Isolated in Hospitals in the Littoral Region of Cameroon. European Journal of Clinical and Biomedical Sciences. Vol. 5, No. 3, 2019, pp. 46-50. doi: 10.11648/j.ejcbs.20190503.12

Received: May 24, 2019; Accepted: July 1, 2019; Published: July 24, 2019

\begin{abstract}
Miniaturized galleries are essential for a good identification of bacteria. The aim of this study was to identify multi-resistant Klebsiellap neumoniae strains in the referral health structures of Cameroon littoral region and establish a digital profile. A cross-sectional and descriptivestudy was conducted during 2016 and early 2017, intermediate susceptibility isolates or resistant to cephalosporins third generation $(\mathrm{C} 3 \mathrm{G})$ were collected in the laboratories of referral hospitals of the Littoral (General Hospital, Laquintinie, Military, Gyneco-obstetrics and pediatrics of Douala and Saint John of Malta of Njombé) and in Diagmed laboratory. The confirmation of the strains was made by the gallery API 20E ${ }^{\mathrm{TM}}$ (BioMérieux). In this study, atotal of 412 strains of Klebsiellasp (species) were isolated. We obtained 125 strains of Klebsiellasp intermediate or resistant to $(\mathrm{C} 3 \mathrm{G})$ and 122 were confirmed to be Klebsiella pneumoniae. The sex ratio (F/ M) was 1.26. Klebsiella pneumoniae pneumonia was the species mostly identified at $82.4 \%$ and the two digital profiles mainly found were 5215773 and 1215773 with respective frequencies of $52.8 \%$ and $18.4 \%$. The biochemical profile: LDC (+), CIT (+), URE (+), IND (-), VP (+), GLU $(+)$, MAN $(+)$, INO $(+)$, SOR $(+)$, RHA $(+)$, SAC $(+)$, MEL $(+)$, ARA $(+)$ was found in all services. There is a high frequency of Klebsiella pneumoniae pneumonia with several different digital profiles, so it is still essential to make a good identification to facilitate the epidemiological data.
\end{abstract}

Keywords: Gallery, Identification, Klebsiella Pneumoniae, Digital Profile

\section{Introduction}

Enterobacteriaceae, like the Klebsielles, occupy an important place in infectious diseases. They are highly prevalent in urinary tract infections (UTI), suppurations and septicemia [1]. The study of the resistance mechanisms of bacteria to antibiotics has made it possible to detect one of the most frequent mechanisms that constitutes enzymatic resistance; Extended spectrum $\beta$-lactamases (ESBL) are a group of enzymes that share the common property of conferring resistance to penicillins, 1st, 2nd and $3 \mathrm{rd}$ generation cephalosporins, to aztreonam (but not to cephamycins and carbapenems). ) by hydrolysis of these antibiotics, which are inhibited by inhibitors of $\beta$-lactamases such as clavulanic acid [2]. These Extended-spectrum $\beta$ lactamases (ESBL) are unique in third-generation cephalosporins [3] and this is because of their genetic determinism. ESBL-producing bacteria are often resistant to several other antibiotics [4].

Commonly, they are two species of the genus Klebsiella: Klebsiellaoxytoca and Klebsiellapneumoniaewith three 
subspecies:

Klebsiellapneumoniaepneumoniae,

Klebsiellapneumoniaeozaenae

and

Klebsiellapneumoniaerhinoscleromatis.

Klebsiellapneumoniae is a bacterial species responsible for nosocomial infections where the digestive tract of hospitalized patients and staff hands are the two main sources of transmission [5]. The identification of bacterial strains is made on the basis of their morphological, cultural and biochemical characters, presumably, an acceptable identification of the family or genus of the strain studied is made. The use of miniaturized galleries is essential for confirmation, including API20 $\mathrm{E}^{\mathrm{TM}}$ from BioMérieux (Aptical Profile Index) which is a standardized system for the identification of enterobacteriaceae and other non-fastidious gram-negative bacilli, including 21 miniaturized biochemical tests, as well as a database. The following will give as result a digital profile for a good identification. The aim of this work was to isolate and identify the multi-resistant Klebsiellapneumoniae strains producing Extended-spectrum $\beta$-Lactamases (ESBL) in the health referral structures of the coastal region of Cameroon.

\section{Materials and Methods}

\subsection{Stud Design}

This was both cross-sectional and descriptive study carried out in several health structures in the Littoral region, namely:

The laboratories of the referral hospitals of Douala (General Hospital, Laquintinie Hospital, Military Hospital, Gyneco-Obstetric and Pediatric Hospital), the Saint John Hospital of Malta of Njombé and the Diagmed Laboratory were used for strains collection.

The central laboratory of the Hospital laquintinie was used for microbiological analyzes. It was conducted over a 14month period, from January 2016 to February 2017.

Transport media (Mueller Hinton sloped in glass and screw tubes) were previously delivered to the Sanitary Structures Laboratory and stored in a refrigerator at $4^{\circ} \mathrm{C}$.

Strains of Klebsiellasp or Klebsiellapneumoniae isolated and identified in the laboratory as intermediate or resistant to a third generation cephalosporin $(\mathrm{C} 3 \mathrm{G})$ were inoculated by the laboratory technician within 2 hours by streaking in screw glass tube and incubated at $37^{\circ} \mathrm{C}$ for $24 \mathrm{~h}$. Then followed the collection.

\subsection{Sample Transport}

The labeled samples (code, date, time of collection) and the closure of the well-controlled screw cap were kept in a NOVALAB TM biosafety plastic package (in accordance with ISO 15189) and placed in a cooler with a cold accumulator. They were sent to the central laboratory of thelaquintiniehospital within 2 hours.

\subsection{Methods}

After the arrival of the strains at the Laquintinie hospital laboratory, the patients' data were recorded on the data sheet in a registryfollowedby the confirmation of the identificationof strainsby the API $20 \mathrm{E}^{\mathrm{TM}}$ gallery and the BioMérieux analytical catalog.

\subsection{Statistical Analysis}

The data was analyzed using SPSS version 16 for Windows (SPSS, Inc., Chicago, IL, USA). Goodness-of-fit test to compare proportions (mixed uni statistic) while Pearson-McNemar chi-square tests were used for bi-varied statistics. The threshold of significance was set at a probability value of less than $5 \%$.

\section{Results}

The number of Klebsiellasp strains isolated in the hospitals laboratories during the study period was 412 and 287 were C3G-sensitive. We obtained a total of 125 Klebsielle intermediate or C3G-resistant strains and 122 strains were identified. And confirmed to be Klebsiellapneumoniae with 106 that produced ESBL (a rate of 86.9\%).

Table 1. Frequency of identified and confirmed Klebsielles strain species.

\begin{tabular}{lll}
\hline Klebsiellespecies & Effective & Frequency (\%) \\
\hline K. oxytoca & 3 & 2,4 \\
K. pneumoniae pneumoniae & 103 & 82,4 \\
K. pneumoniae ozaenae & 15 & 12,0 \\
K. pneumoniae rhinoscleromatis & 4 & 3,2 \\
Total & 125 & 100 \\
\hline
\end{tabular}

$\mathrm{P}<0,05 ; \mathrm{df}=3 ;$ Chi-square $=31,07$ (chi-squares of homogeneity): significant df: degree of freedom.

Klebsiella pneumoniaepneumoniae was the subspecies that was predominantly identified with a frequency of $82.4 \%$, followed by Klebsiella pneumoniaozaenae $12.0 \%$ and Klebsiella pneumonia rhinoscleromatis $3.2 \%$.

Table 2. Digital profile of identified Klebsielles species.

\begin{tabular}{llll}
\hline Digital profile & Species & N & \% \\
\hline 5215773 & K. pneumoniaepneumoniae & 66 & 52,8 \\
1215773 & K. pneumoniaepneumoniae & 23 \\
5205773 & K. pneumoniaepneumoniae & 18,4 & 6 \\
1214673 & K. pneumoniaepneumoniae & 6,4 & 4,2 \\
\hline
\end{tabular}




\begin{tabular}{llll}
\hline Digital profile & Species & N & $\%$ \\
\hline 1215771 & K. pneumoniaepneumoniae & 2 & 1,6 \\
5204543 & K. pneumoniaeozaenae & 9 & 7,2 \\
1204541 & K. pneumoniaeozaenae & 4 & 3,2 \\
1204741 & K. pneumoniaeozaenae & 2 & 1,6 \\
1000321 & K. pneumoniaerhinoscleromatis & 2 & 1,6 \\
1000521 & K. pneumoniaerhinoscleromatis & 2 & 1,6 \\
1254763 & K. oxytoca & 2 & 1,6 \\
1254773 & K. oxytoca & 1 & 0,8 \\
Total & & 125 & 100 \\
\hline
\end{tabular}

$\mathrm{P}<0.05 ; \mathrm{df}=12 ;$ Chi-square $=72.14$ (chi-square of homogeneity): significant.

The two digital profiles mainly found were 5215773 and 1215773 with respective frequencies of $52.8 \%$ and $18.4 \%$. Five different digital profiles of Klebsiella pneumonia pneumoniae were found in the hospitals of the littoral region, Cameroon.

Table 3. Biochemical profile of Klebsielles species identified in various services.

\begin{tabular}{|c|c|c|c|c|c|c|c|c|}
\hline \multirow{2}{*}{ Species } & \multicolumn{7}{|l|}{ Profile } & \multirow{2}{*}{ P-value } \\
\hline & CHI & EXT & GYN & MED & NEO & PED & REA & \\
\hline \multirow{13}{*}{ K. pneumoniapneumoniae } & $\operatorname{LDC}(+)$ & $\mathrm{LDC}(+)$ & $\operatorname{LDC}(+)$ & $\operatorname{LDC}(+)$ & $\operatorname{LDC}(+)$ & LDC (+) & LDC (+) & 1 \\
\hline & $\operatorname{CIT}(+)$ & $\operatorname{CIT}(+)$ & $\operatorname{CIT}(+)$ & CIT $(+)$ & $\operatorname{CIT}(+)$ & $\mathrm{CIT}(+)$ & $\operatorname{CIT}(+)$ & 1 \\
\hline & $\operatorname{URE}(+)$ & $\operatorname{URE}(+)$ & $\operatorname{URE}(+)$ & $\operatorname{URE}(+)$ & $\operatorname{URE}(+)$ & $\operatorname{URE}(+)$ & $\operatorname{URE}(+)$ & 1 \\
\hline & IND (-) & IND (-) & IND (-) & IND (-) & IND (-) & IND (-) & $\operatorname{IND}(-)$ & 1 \\
\hline & $\mathrm{VP}(+)$ & $\mathrm{VP}(+)$ & $\mathrm{VP}(+)$ & $\mathrm{VP}(+)$ & $\mathrm{VP}(+)$ & $\mathrm{VP}(+)$ & $\mathrm{VP}(+)$ & 1 \\
\hline & GLU $(+)$ & GLU $(+)$ & GLU $(+)$ & GLU $(+)$ & GLU $(+)$ & GLU $(+)$ & GLU (+) & 1 \\
\hline & MAN $(+)$ & MAN $(+)$ & MAN $(+)$ & MAN $(+)$ & MAN $(+)$ & MAN $(+)$ & MAN (+) & 1 \\
\hline & INO $(+)$ & INO $(+)$ & INO $(+)$ & INO $(+)$ & INO $(+)$ & INO $(+)$ & INO $(+)$ & 1 \\
\hline & $\operatorname{SOR}(+)$ & $\operatorname{SOR}(+)$ & $\operatorname{SOR}(+)$ & SOR $(+)$ & $\operatorname{SOR}(+)$ & $\operatorname{SOR}(+)$ & $\operatorname{SOR}(+)$ & 1 \\
\hline & $\mathrm{RHA}(+)$ & RHA $(+)$ & RHA (+) & RHA (+) & RHA (+) & RHA (+) & RHA (+) & 1 \\
\hline & $\mathrm{SAC}(+)$ & $\mathrm{SAC}(+)$ & SAC $(+)$ & SAC $(+)$ & $\mathrm{SAC}(+)$ & SAC (+) & $\mathrm{SAC}(+)$ & 1 \\
\hline & $\operatorname{MEL}(+)$ & $\operatorname{MEL}(+)$ & $\operatorname{MEL}(+)$ & $\operatorname{MEL}(+)$ & $\operatorname{MEL}(+)$ & $\operatorname{MEL}(+)$ & $\operatorname{MEL}(+)$ & 1 \\
\hline & $\operatorname{ARA}(+)$ & $\operatorname{ARA}(+)$ & $\operatorname{ARA}(+)$ & $\operatorname{ARA}(+)$ & $\operatorname{ARA}(+)$ & $\operatorname{ARA}(+)$ & $\operatorname{ARA}(+)$ & 1 \\
\hline \multirow{13}{*}{ K. pneumoniaeozaenae } & $\operatorname{LDC}(+)$ & $\mathrm{LDC}(+)$ & $\operatorname{LDC}(+)$ & $\mathrm{LDC}(+)$ & $\operatorname{LDC}(-)$ & $\mathrm{LDC}(+)$ & LDC (-) & 0,83 \\
\hline & $\operatorname{CIT}(+)$ & $\operatorname{CIT}(+)$ & $\operatorname{CIT}(+)$ & $\operatorname{CIT}(+)$ & CIT (-) & $\operatorname{CIT}(+)$ & CIT $(+)$ & 1 \\
\hline & URE (-) & URE (-) & URE (-) & URE (-) & URE (-) & URE (-) & URE (-) & 1 \\
\hline & IND (-) & IND (-) & $\operatorname{IND}(-)$ & $\operatorname{IND}(-)$ & $\operatorname{IND}(-)$ & $\operatorname{IND}(-)$ & $\operatorname{IND}(-)$ & 1 \\
\hline & VP (-) & VP (-) & VP (-) & VP (-) & VP (-) & VP (-) & VP (-) & 1 \\
\hline & GLU $(+)$ & GLU $(+)$ & GLU (+) & GLU (+) & GLU $(+)$ & GLU (+) & GLU (-) & 1 \\
\hline & MAN (+) & MAN (+) & MAN (+) & MAN (+) & MAN (-) & MAN (+) & MAN (-) & 1 \\
\hline & INO (-) & INO (-) & INO $(+)$ & INO $(+)$ & INO (-) & INO (-) & INO (-) & 0,48 \\
\hline & SOR $(+)$ & SOR $(+)$ & SOR $(+)$ & SOR $(+)$ & SOR (-) & $\mathrm{SOR}(+)$ & SOR (-) & 1 \\
\hline & RHA (-) & RHA (-) & RHA (-) & RHA (-) & RHA (-) & RHA (-) & RHA (-) & 1 \\
\hline & SAC (-) & SAC (-) & SAC (-) & SAC (-) & SAC (-) & SAC (-) & SAC (-) & 1 \\
\hline & $\operatorname{MEL}(+)$ & $\operatorname{MEL}(+)$ & $\operatorname{MEL}(+)$ & $\operatorname{MEL}(+)$ & MEL (-) & $\operatorname{MEL}(+)$ & MEL (-) & 1 \\
\hline & $\operatorname{ARA}(+)$ & $\operatorname{ARA}(+)$ & $\operatorname{ARA}(+)$ & $\operatorname{ARA}(+)$ & ARA (-) & $\operatorname{ARA}(+)$ & ARA (-) & 0,83 \\
\hline \multirow{13}{*}{$\begin{array}{l}\text { K. } \\
\text { pneumoniaerhinoscleromatis }\end{array}$} & LDC (-) & LDC (-) & LDC (-) & LDC (-) & LDC (-) & LDC (-) & LDC (-) & 1 \\
\hline & CIT (-) & CIT (-) & CIT (-) & CIT (-) & CIT (-) & CIT (-) & CIT (-) & 1 \\
\hline & URE (-) & URE (-) & URE (-) & URE (-) & URE (-) & URE (-) & URE (-) & 1 \\
\hline & IND (-) & IND (-) & $\operatorname{IND}(-)$ & $\operatorname{IND}(-)$ & $\operatorname{IND}(-)$ & $\operatorname{IND}(-)$ & $\operatorname{IND}(-)$ & 1 \\
\hline & VP (-) & $\mathrm{VP}(-)$ & VP $(-)$ & $\mathrm{VP}(-)$ & VP (-) & $\mathrm{VP}(-)$ & $\mathrm{VP}(-)$ & 1 \\
\hline & GLU (-) & GLU (-) & GLU (-) & GLU (-) & GLU (-) & GLU (-) & GLU (-) & 1 \\
\hline & MAN (-) & MAN (-) & MAN (-) & MAN (+) & MAN (+) & MAN (-) & MAN (-) & 1 \\
\hline & INO (-) & INO (-) & INO (-) & INO (+) & INO (+) & INO (-) & INO (-) & 1 \\
\hline & SOR (-) & SOR (-) & SOR (-) & SOR (+) & SOR (+) & SOR (-) & SOR (-) & 1 \\
\hline & RHA (-) & RHA (-) & RHA (-) & RHA (-) & RHA (-) & RHA (-) & RHA (-) & 1 \\
\hline & SAC (-) & SAC (-) & SAC (-) & SAC (+) & SAC (+) & SAC (-) & SAC (-) & 1 \\
\hline & MEL (-) & MEL (-) & MEL (-) & MEL (-) & MEL (-) & MEL (-) & MEL (-) & 1 \\
\hline & ARA (-) & ARA (-) & ARA (-) & ARA (-) & ARA (-) & ARA (-) & ARA (-) & 1 \\
\hline \multirow{9}{*}{ K. oxytoca } & LDC (-) & LDC (-) & LDC (-) & LDC (-) & $\operatorname{LDC}(-)$ & LDC (-) & $\operatorname{LDC}(-)$ & 1 \\
\hline & CIT (-) & CIT $(+)$ & CIT $(+)$ & CIT (-) & CIT $(+)$ & CIT (-) & CIT (-) & 1 \\
\hline & URE (-) & $\operatorname{URE}(+)$ & $\operatorname{URE}(+)$ & URE (-) & $\operatorname{URE}(+)$ & URE (-) & URE (-) & 1 \\
\hline & IND (-) & IND $(+)$ & $\operatorname{IND}(+)$ & $\operatorname{IND}(-)$ & $\operatorname{IND}(+)$ & $\operatorname{IND}(-)$ & $\operatorname{IND}(-)$ & 1 \\
\hline & $\mathrm{VP}(-)$ & $\mathrm{VP}(-)$ & VP (-) & $\mathrm{VP}(-)$ & $\mathrm{VP}(-)$ & $\mathrm{VP}(-)$ & VP (-) & 1 \\
\hline & GLU (-) & GLU (+) & GLU (+) & GLU (-) & GLU (+) & GLU (-) & GLU (-) & 1 \\
\hline & MAN (-) & MAN (+) & MAN (+) & MAN (-) & MAN (+) & MAN (-) & MAN (-) & 1 \\
\hline & INO (-) & INO (+) & $\mathrm{INO}(+)$ & $\mathrm{INO}(-)$ & $\mathrm{INO}(+)$ & INO (-) & $\mathrm{INO}(-)$ & 1 \\
\hline & SOR (-) & SOR $(+)$ & SOR $(+)$ & SOR (-) & SOR $(+)$ & SOR (-) & SOR (-) & 1 \\
\hline
\end{tabular}




\begin{tabular}{|c|c|c|c|c|c|c|c|c|}
\hline \multirow{6}{*}{ Species } & \multicolumn{7}{|l|}{ Profile } & \multirow{2}{*}{ P-value } \\
\hline & CHI & EXT & GYN & MED & NEO & PED & REA & \\
\hline & RHA (-) & RHA (-) & RHA (+) & RHA (-) & RHA (-) & RHA (-) & RHA (-) & 0,22 \\
\hline & SAC (-) & $\mathrm{SAC}(+)$ & $\mathrm{SAC}(+)$ & SAC (-) & SAC $(+)$ & SAC (-) & SAC (-) & 1 \\
\hline & MEL (-) & $\operatorname{MEL}(+)$ & $\operatorname{MEL}(+)$ & MEL (-) & $\operatorname{MEL}(+)$ & $\operatorname{MEL}(-)$ & MEL (-) & 1 \\
\hline & ARA (-) & $\operatorname{ARA}(+)$ & $\operatorname{ARA}(+)$ & ARA (-) & $\operatorname{ARA}(+)$ & $\operatorname{ARA}(-)$ & ARA (-) & 1 \\
\hline
\end{tabular}

CHI: Surgery, EXT: External, GYN: Gynecology; MED: Medicine; NEO: Neonatalogy; PED: Pediatric; REA: Intensive care unit.

LDC: lysine De Carboxylase, CIT: Citrate, URE: Urea, IND: Indol, VP: Voges Prauskauer, GLU: Glucose, MAN: Mannitol, INO: Inositol, SOR: Sorbitol, RHA: Rhamnose, SAC: Saccharose, MEL: Mélose, ARA: Arabinose.

We observed the same biochemical profile of Klebsiellapneumoniaepneumoniae LDC (+), CIT (+), URE (+), IND (-), VP (+), GLU (+), MAN (+), INO (+), SOR $(+)$, RHA $(+), \operatorname{SAC}(+), \operatorname{MEL}(+), \operatorname{ARA}(+)$ which was present in all services.

\section{Discussion}

\subsection{ESBL Production}

ESBL production in our study was $86.9 \%$, comparable to Feizabadi in Iran in the order of $72.1 \%$ for K. pneumoniae [11], Dadeic-Ljubovic in Bosnia and Herzegovina with 88, $8 \%$ in enterobacteria [12]. In the same order as Elhani reports in Tunisia; the production of ESBL by K. pneumoniae varies and can reach $87.5 \%$ in pediatric intensive care units [13], a study conducted in Yaoundé (Cameroon) gave a rate of $66.3 \%$ [14] Hailaji reports that $20.4 \%$ of ESBL are produced by Klebsiella species in Nouakchott, Mauritania [15] and its production in Sudan was 44.4\% [16]. Thus, ESBL prevalence rates vary widely according to geographical location and bacterial species and there is a causal link between the increased use of third-generation cephalosporins and the emergence of ESBLs.

\subsection{Frequency of Identified and Confirmed Klebsiella Species Producing ESBL}

\subsubsection{Klebsielle Species}

The ESBL-producing strains of Klebsiella pneumoniaepneumoniae and Klebsiella pneumoniaeozaenae were isolated at frequencies of $82.4 \%$ and $12.0 \%$, respectively, similar to the $90 \%$ and $10 \%$ found by Chafabetbeui in Yaoundé in 2015. The frequency of Klebsiella pneumoniaerhinoscleromatis isolated is $3.2 \%$, this differences from the result of Chafa-betbeui where none of this isolated subspecies were producing ESBL [6]

\subsubsection{Digital Profile of Identified Klebsiella Species}

5215773 is the digital profile mostly found with a frequency of $52.8 \%$; close to $60 \%$ found in Annaba in Algeria by ZinebBelbel in 2014 [7]. Sekhri-Arafa found in a study in Constantine in Algeria in 2011 a higher frequency of about $78.23 \%$ [8]. This is how we can say that profile 5215773 is the most predominant in the species Klebsiellapneumoniae. This is the profile par excellence of Klebsiellapneumoniae.

Sekhri-arafa and ZinebBelbel found respectively the lowest frequencies of $2,94 \%$ and $3 \%$ corresponding to the profile 5205573 (urea-, inositol-) which was not obtained in our study in Cameroon. This profile was found in France by Decré of the order of 7\% [9].

We obtained the profile 5205773 (urea -, Inositol +) at
$6.4 \%$, similar to the frequency of 7, 64\% obtained by Sekriarafa [8] and contrary to the high frequency of $61.5 \%$ obtained by Decré in France [9]. Sekhri-Arafa and ZinebBelbel had respectively obtained in Constantine and Annaba in Algeria during their studies, 5 different digiatal profiles $[7,8]$ contrary to our study in the Cameroon littoral region where there were 10 distinct digital profiles. This can be explained by the fact that their studies were conducted only in one hospital while we did ours in an entire region and in six health facilities. In addition the littoral region is a cosmopolitan zone. Nevertheless, we mainly met 4 profiles $(5215773,1215773,5204543$, and 5205773) with respective frequencies of $52.8 \%, 18.4 \%, 7.2 \%$ and $6.4 \%$.

The profile 5215773 has been found in all the hospitals services in the littoral region, the same is true for the study of Sekhri-arafa in Constantine where this profile remains predominant in services [8].

The digital profiles: 5204543, 1204541 and 1204741 corresponding to Klebsiellapneumoniaeozaenae were obtained at the total frequency of $12.0 \%$ and (1000321.1000521) corresponding to Klebsiellapneumoniaerhinoscleromatis at 3.2\%; None of his different profiles were found at the University Hospital of Constantine, nor that of Annaba in Algeria.

\subsection{Biochemical Profile}

The biochemical profile par excellence of Klebsiellapneumoniae is: ONPG $(+), \operatorname{ADH}(-), \operatorname{LDC}(+)$, ODC (-), CIT (+), H2S (-), UREA (+), TDA (-), IND (-), VP $(+)$, GEL $(-)$, GLU $(+)$, MAN $(+)$, INO $(+)$, SOR $(+)$, RHA $(+)$, SAC (+), MEL $(+)$, AMY (+), ARA $(+)$, it is the same for the studies made in Annaba and Constantine in Algeria respectively by ZinebBelbel in 2014 [7] and Sekhri-arafa [8]. The rare biochemical profile of Klebsiellapneumoniae with (Urea -, Inositol-) corresponding to 5205573 was not observed in our study, but was found in Constantine. The less frequent profile of Klebsiellapneumoniae with (Urea -, Inositol + ) corresponding to 5205773 was observed with a frequency of $6.4 \%$ as much as Sekhri-Arafa which obtained it at $7.64 \%$.

We found the same biochemical profile: $\operatorname{LDC}(+)$, CIT $(+)$, URE (+), IND (-), VP (+), GLU $(+), \operatorname{MAN}(+), \operatorname{INO}(+)$, SOR $(+))$, RHA $(+)$, SAC $(+)$, MEL $(+)$, ARA $(+)$ found in all the services for the case of Klebsiellapneumoniaepneumoniae. This may also be explained by the fact that the staff hands are also a main 
source of propagation of nosocomial infections [5] which is contrary to Okalla-Ebongue who found $2 / 3$ of the same profile of Klebsiellapneumoniaein all services [10].

\section{Conclusion}

Klebsiella pneumoniae pneumoniae is the subspecies mainly isolated; the study shows a high frequency of Klebsiella pneumoniae pneumoniae with different digital profiles. Due to this, it is still essential to make a good bacterial identification to facilitate epidemiological data to better identify the multi-resistant strains circulating in hospitals and monitor their dissemination. The digital profile (5215773) is mainly found in our study on Klebsiella pneumoniae.

\section{Contributions of the Authors}

JT, COE, DA participated in the design, analysis and interpretation of the data. CY to data analysis and interpretation, JT to data collection and manuscript design. All authors contributed to the review and approved the final version.

\section{Conflicts of Interest}

All the authors do not have any possible conflicts of interest.

\section{Acknowledgements}

The authors kindly thank the directors of the littoral region hospitals of Cameroon and the staff of the Departments of Microbiology Laboratories for participating in sample collection. We also acknowledge Danchi Henriette, Dongmo. F. B. Rostand, Ngaheu Pierre-Rostand, and Tsaplon Doumbe Leslie from DIAGMED laboratory for their support.

\section{References}

[1] Kumamoto Y, Tsukamoto T, Matsukawa M, Kunishima Y, Hirose T, Imafuku $\mathrm{Y}$ et al. Comparative studies on activities of antimicrobial agents against causative organisms isolated from patients with urinary tract infections (2004). I. Susceptibility distribution. Jpn J Antibiot. 2006 Jun; 59 (3): 177-200.

[2] Bush K, Jacoby GA, Medeiros AA. A functional classification scheme for beta-lactamases and its correlation with molecular structure. Antimicrob Agents Chemother. 1995; 39 (6): 12111233.

[3] Guessennd N, Kacou-N'doubaA, GbononV, YapiD, EkazaE, Dosso $M$ et al. Prévalence et profil de résistance des entérobactéries productrices de beta-lactamasesa spectre élargi (BLSE) à Abidjan Côte d'ivoire de 2005 à 2006. J. sci. pharm. biol. 2008; 9 (1): 63-70.

[4] Philippon A, Arlet G, and Lagrange PH. Origin and impact of plasmid-mediated extendedspectrum beta-lactamases. Eur J ClinMicrobiolInfect Dis. 1994; 13 (1): S17-29.

[5] Freney J, Leclerq R, Riegel P. Précis de Bactériologie clinique. 2è édition. Paris: Editions ESKA; 2007. p. 1012.

[6] Chafa-BetbeuiA, Gonsu-Kamga H, Toukam M, Mbakop CD, Enjema-Lyonga E, Bilong S et al. Phenotypic Detection of Extended Spectrum Beta-Lactamase and Carbapenemases Produced by Klebsiellaspp Isolated from Three Referrals Hospitals in Yaounde, Cameroon. BrMicrobiologyRes J. 2015; 9 (1): 1-9.

[7] Zineb-Belbel. Evaluation de la résistance aux antibiotiques des souches deKlebsiellapneumoniaeisolées dans les hôpitaux de la ville d'Annaba. Thèse de Doctorat en microbiologie. Université Badji Mokhtar Annaba; 2014, 66-67.

[8] Sekhri-Arafa. Fréquence et marqueurs épidémiologiques de Klebsiellapneumoniaedans les services à haut risque infectieux au niveau du CHU Benbadis de Constantine. Thèse de Doctorat en Biochimie et Microbiologie. Université Mentouri de Constantine; 2011, 92-96.

[9] Decré D, Gachot B, Lucet JC, Arlet G, Régnier B. Surveillance épidémiologique des souches de Klebsiellapneumoniae productrices de $\beta$-lactamases à spectre étendu (K. p BLSE) dans un service de réanimation. Rev Française des laboratories. 2000; 2000 (320): 31-38.

[10] Okalla-Ebongue C, Mayoudom-Nguatcheussi C, Nda-Mefo JP, Bollanga J, Adiogo D, Namme-Luma H. Microbial Ecology and Antibiotic Susceptibility Profile of Germs Isolated from Hospital Surfaces and Medical Devices in a Reference Hospital in Douala (Cameroon). Scientific Research. 2018; 8 (2): 125-137.

[11] Feizabadi MM, Mahamadi-Yeganeh S, Mirsalehian A, Mirafshar SM, Mahboobi M, Nili F, et al. Genetic characterization of ESBL producing strains of Klebsiella pneumoniae fromTehran hospitals. J Infect Dev Ctries. 2010; 4 (10): 609-615.

[12] Dedeic-Ljubovic A, Hukic M, Pfeifer Y, Witte W, Padilla E, López-Ramis I, Albertí S. Emergence of CTX-M-15 extended-spectrum beta-lactamase-producing Klebsiella pneumoniae isolates in Bosnia and Herzegovina. Clin Microbiol Infect. 2010; 16 (2): 152-6.

[13] Elhani D, Bakir L, Mahjoub A. Changement de l'épidémiologie de Klebsiella pneumoniae productrice de $\beta$ lactamases à spectre élargi. J Pat Bio. 2011; 69 (5): 523-9.

[14] Djuikoue IC, Woerther PL, Toukam M, Burdet C, Ruppé E, Gonsu KH et al. Intestinal carriage of Extended Spectrum Beta-Lactamase producing E. coli in women with urinary tract infections, Cameroon. J Infect Dev Ctries. 2016 Oct 31; 10 (10): 1135-1139.

[15] Hailaji NSM, Ould-Salem ML, Ghaber SM. La sensibilité aux antibiotiques des bactéries Uropathogènes dans la ville de Nouakchott-Mauritanie. J. Purol. 2016; 26 (6): 346-352.

[16] Abd Elrahman Mustafa Abd Elrahman Osman, Shingray Osman Hashim, Mohammed Abdall Musa, Omer Mohammed Tahir. Detection of CTX-M, TEM and SHV Genes in Gram Negative Bacteria Isolated from Nosocomial Patients at Port Sudan Teaching Hospital. European Journal of Clinical and Biomedical Sciences. 2017; 3 (6): 101-108. 